\title{
Relationship between sexual hormones, quality of life and postmenopausal sexual function
}

\author{
Relação entre hormônios sexuais, qualidade de vida e função sexual \\ na pós-menopausa
}

Clayton Peixoto, ${ }^{1,2,3}$ (D) Carolina Gomes Carrilho, ${ }^{3}$ Tatiana Teixeira de Siqueira Bilemjian Ribeiro, ${ }^{3}$ Lucy Maria da Silva, ${ }^{3}$ Emerson Andrade Gonçalves, ${ }^{3}$ Luísa Fernandes, ${ }^{3}$ Antonio Egidio Nardi, ${ }^{1}$ Adriana Cardoso, ${ }^{1,2,3}$ André Barciela Veras ${ }^{1,2,3}$

\begin{abstract}
Objective: To assess the relationship between sexual hormones, sexual function and quality of life in postmenopausal women. Method: A cross-sectional study was conducted with a convenience sample of 36 postmenopausal women between the ages of 45 and 65 in follow-up at a climacteric outpatient clinic. Mood, quality of life, sexual function and hormonal profile were assessed.

Results: With regard to sexual hormones and sexual function, a relationship was found between orgasm and luteinizing hormone $(r=0.37)$, orgasm and sex hormone-binding globulin (SHBG) $(r=0.39)$, SHBG and less pain $(r=0.44)$, dehydroepiandrosterone (DHEA) and desire $(r=-0.45)$, as well as between prolactin and lubrication $(r=0.33)$. Sexual hormones and quality of life were related as follows: progesterone and limitations due to physical aspects $(r=0.35)$, SHBG and social aspects $(r=0.35)$, cortisol and pain $(r=0.46)$, DHEA and social aspects $(r=-0.40)$. Finally, the following relationships were found between sexual function and quality of life: sexual desire and vitality, social aspects, state of general health and mental health $(r=0.46, r=0.51, r=0.35$, and $r=0.38$, respectively). Arousal, orgasm and satisfaction with sexual life showed a relationship with less physical pain $(r=0.40$, $r=0.42$, and $r=0.43$, respectively). Satisfaction with sexual life was correlated with vitality $(r=0.33)$.

Conclusion: Different correlations than expected were found in this study regarding the effect of some hormones on sexual function and some aspects of the quality of life of postmenopausal women.
\end{abstract}

Keywords: Sexual hormones, sexual dysfunction, well-being, quality of life, women, postmenopausal.

\section{Resumo}

Objetivo: Avaliar a relação entre hormônios sexuais, função sexual e qualidade de vida em mulheres na pós-menopausa.

Métodos: Estudo transversal com amostra de conveniência de 36 mulheres na pós-menopausa, com idades entre 45 e 65 anos, em seguimento ambulatorial de climatério. Humor, qualidade de vida, função sexual e perfil hormonal foram avaliados.

Resultados: Entre hormônios sexuais e função sexual, foi encontrada relação entre orgasmo e hormônio luteinizante $(r=0,37)$, orgasmo e globulina ligadora de hormônios sexuais (SHBG) $(r=0,39)$, SHBG e menos dor $(r=0,44)$, desidroepiandrosterona (DHEA) e desejo $(r=-0,45)$, bem como entre prolactina e lubrificação $(r=0,33)$. Entre hormônios sexuais e qualidade de vida: progesterona e limitações por aspectos físicos $(r=0,35)$, SHBG e aspectos sociais $(r=0,35)$, cortisol e dor $(r=0,46)$, DHEA e aspectos sociais $(r=-0,40)$. Por fim, entre função sexual e qualidade de vida: desejo sexual e vitalidade, aspectos sociais, estado geral de saúde e saúde mental $(r=0,46$, $r=0,51, r=0,35$ e $r=0,38$, respectivamente). Excitação, orgasmo e satisfação com a vida sexual mostraram uma relação com menos dor física ( $r=0,40, r=0,42$ e $r=0,43$, respectivamente). A satisfação com a vida sexual foi correlacionada com a vitalidade $(r=0,33)$.

Conclusão: Correlações diferentes das esperadas foram encontradas neste estudo em relação ao efeito de alguns hormônios sobre a função sexual e alguns aspectos da qualidade de vida de mulheres na pós-menopausa.

Descritores: Hormônios sexuais, disfunção sexual, bem-estar, qualidade de vida, mulheres, pós-menopausa.

\footnotetext{
${ }^{1}$ Laboratório de Pânico e Respiração, Instituto de Psiquiatria (IPUB), Universidade Federal do Rio de Janeiro (UFRJ), Rio de Janeiro, RJ, Brazil. ${ }^{2}$ Universidade Federal de Mato Grosso do Sul (UFMS), Campo Grande, MS, Brazil. ${ }^{3}$ Universidade Católica Dom Bosco, Campo Grande, MS, Brazil. Submitted Jun 24 2018, accepted for publication Sep 182018.

Suggested citation: Peixoto C, Carrilho CG, Ribeiro TTSB, da Silva LM, Gonçalves EA, Fernandes L, et al. Relationship between sexual hormones, quality of life and postmenopausal sexual function. Trends Psychiatry Psychother. 2019;41(2):136-143. http://dx.doi.org/10.1590/2237-6089-2018-0057
} 


\section{Introduction}

Menopause is an event that marks the end of the female reproductive period and the onset of the non-reproductive phase known as postmenopause. Postmenopause is a period experienced critically by the majority of women due to changes caused by ovarian failure. It is estimated that the symptoms common to this period reach approximately $80 \%$ of the women with different levels of intensity. ${ }^{1}$ Hot flashes, decreased physical strength and energy, alterations in sleep, mood, urinary tract, cognition and sexual function are common complaints in this phase. ${ }^{2}$

Although the actual impact of menopause on sexual function is not totally clear, hypoestrogenism is known to be directly responsible for the loss of vaginal lubrication and the consequent increase in the incidence of dyspareunia, ${ }^{3}$ just as the drastic reduction of testosterone levels is responsible for the reduction of libido. ${ }^{4}$ These two factors can be responsible for a decrease in the frequency of sexual relations, as reported in a few studies. ${ }^{5-7} A$ Brazilian study involving postmenopausal women between the ages of 45 and 60 found a relationship between sexual satisfaction and lower intensity of climacteric symptoms, ${ }^{5}$ a finding that has been corroborated by another study with a Chilean population. ${ }^{6}$

As sexuality is one of the pillars of quality of life, ${ }^{5}$ sexual dysfunctions, which increase significantly with aging, tend to contribute in a very significant way to the loss of quality of life in this population. Quality of life among postmenopausal women is a topic of growing interest, especially due to the increased share of female population that enters the postmenopausal period every year.

Despite the existence of many studies assessing issues related to quality of life in postmenopausal women, ${ }^{8-10}$ as well as others that assess sexuality or hormonal alterations occurring in this period, ${ }^{11,12}$ studies that investigate the relationship between these three aspects, normally affected by postmenopause, are not usually found in literature. Therefore, this work aims to assess the relationships between sexual hormones, sexual function and quality of life in postmenopausal women.

\section{Methodology}

We conducted a cross-sectional study, using a convenience sample comprised of 36 patients receiving follow-up treatment at the climacteric outpatient clinic at the Centro de Referência à Saúde da Mulher (CEAM/ CEM) in Campo Grande, state of Mato Grosso do Sul,
Brazil. The sample comprised women aged between 45 and 65 years, with a gynecological diagnosis of postmenopause (menopause occurred more than 12 months ago) and in current follow-up at a gynecological outpatient clinic specialized in menopausal complaints. Women younger than 45 years or older than 65 years were excluded from the study, as were women who menstruated at least once in the last 12 months, women who underwent bilateral oophorectomy but did not meet the other inclusion criteria, and women with diabetes or other metabolic conditions that could significantly alter the hormonal pattern expected for this life stage.

The study was conducted in accordance with ethical standards and was approved by the research ethics committee of Universidade Anhanguera-Uniderp. All participants signed an informed consent form. Those who met the inclusion criteria and agreed to take part in the study carried through the assessment, conducted in three stages: first stage, mood, quality of life and sexuality assessment; second stage, cognitive profile assessment (data not shown in this article); and third stage, blood collection for hormonal assessment.

Quality of life was assessed using the Brazilian version of the 36-Item Short Form Health Survey (SF36). This instrument comprises 36 items that assess eight areas related to quality of life: functional capacity, physical aspects, pain, general health, vitality, social aspects, emotional aspects and mental health. Each area presents scores that may vary between 0 to 100 , where 0 indicates the worst condition in that area and 100 indicates the best one. ${ }^{13}$

Sexual function was assessed using the Brazilian version of the Female Sexual Function Index (FSFI). The 19 items contained in this instrument assess six aspects of sexual function: desire, arousal, lubrication, orgasm, satisfaction and pain. Desire dimension scores may vary between 1.2 and 6 ; all the other dimensions can present scores between 0 and 6 . Even though each subscale can be individually assessed, the sum of all subscale scores yield a total score, which may range between 1.2 and 36 . Lower scores in any dimension, as well as in the total score, indicate sexual dysfunction. ${ }^{14}$

Hormonal assessment was conducted for the following hormones: luteinizing hormone (LH), follicle stimulating hormone (FSH), estradiol, progesterone, total testosterone ( $\mathrm{T}$-Total), free testosterone (T-Free), sex hormone-binding globulin (SHBG), cortisol, prolactin, androstenedione, dehydroepiandrosterone (DHEA) and dehydroepiandrosterone sulfate (DHEA-S). Blood collection for hormonal assessment occurred between 7:00 and 9:00 in the morning. All patients were on a 12-hour fasting period. The material used for hormonal assessment was the serum, and the method of hormonal 
analysis was chemiluminescence for all hormones, except DHEA, where radioimmunoassay was used.

\section{Data analysis}

Descriptive data were presented as gross numbers. Percentages for categorical variables and as mean and standard deviation (SD) for continuous variables. Data analysis was performed using a two-tailed Pearson correlation test. There were no missing values. Significance was set at $p<0.05$. Data were analyzed using the Statistical Package for the Social Sciences (SPSS) version 20.0.

\section{Results}

The sample was comprised predominantly of married women $(63 \%, \mathrm{n}=23)$, who declared themselves a stayat-home or students (44\%, $n=16)$, Catholics ( $47.2 \%$ $\mathrm{n}=17)$, with a mean age of 55.3 years $(S D=4.6)$, having studied for a mean of 7.3 years $(S D=4.4)$ and having a mean of 2.6 children $(S D=1.7)$. More details on the general characteristics of the sample can be seen in Table 1. The hormonal profile can be seen in Table 2 and the scores related to sexual function and quality of life are described in Table 3.

Table 1 - General characteristics of the sample

\begin{tabular}{|c|c|}
\hline & n (\%) or mean (SD) [min; max] \\
\hline Age & $55.39(4.68)[\min =45 ; \max =65]$ \\
\hline Family income (Brazilian reais)* & $1,770.92(849.62)[\min =300.00 ; \max =4,000.00]$ \\
\hline Years of study & $7.33(4.49)[\min =0 ; \max =17]$ \\
\hline \multicolumn{2}{|l|}{ Occupation } \\
\hline Student/Stay-at-home & $16(44.4)$ \\
\hline Unemployed & $2(5.6)$ \\
\hline Working & $11(30.6)$ \\
\hline Medical license & $4(11.1)$ \\
\hline Retired & $3(8.3)$ \\
\hline \multicolumn{2}{|l|}{ Marital status } \\
\hline Single & $3(8.3)$ \\
\hline Married/civil union & $23(63.9)$ \\
\hline Divorced/separated & $5(13.9)$ \\
\hline Widow & $5(13.9)$ \\
\hline \multicolumn{2}{|l|}{ Pregnancies } \\
\hline Number of pregnancies & $3.11(2.36)[\min =0 ; \max =14]$ \\
\hline Number of births & $2.56(1.66)[\min =0 ; \max =9]$ \\
\hline Number of natural abortions & $0.47(1.13)[\min =0 ; \max =5]$ \\
\hline Number of provoked abortions & $0.11(0.3)[\min =0 ; \max =2]$ \\
\hline \multicolumn{2}{|l|}{ Children } \\
\hline Has kids & $34(94.4)$ \\
\hline Number of children & $2.67(1.74)[\min =0 ; \max =9]$ \\
\hline \multicolumn{2}{|l|}{ General health and lifestyle } \\
\hline Hypertension & $6(16.7)$ \\
\hline Cardiopathy & $2(5.6)$ \\
\hline Smoking & $3(8.3)$ \\
\hline Alcoholism & 0 \\
\hline Practice of physical activity & $14(38.9)$ \\
\hline
\end{tabular}

Max = maximum; $\min =$ minimum.

* Exchange rate at time of study: 1 real $=0.33$ U.S. dollar. 
The following relationships between sexual hormones and aspects of sexual function described by the FSFI were found: moderate positive relationship between orgasm and $\mathrm{LH}(r=0.37 ; \mathrm{p}=0.02)$ and between orgasm and SHBG $(r=0.39 ; p=0.01)$. SHBG also presented moderate correlations with the FSFI dimensions of pain $(r=0.44 ; \mathrm{p}<0.01)$ and satisfaction $(r=0.33 ; \mathrm{p}=0.04)$, and with the total FSFI score $(r=0.39 ; p=0.02)$. DHEA presented a moderate negative correlation with desire $(r=-0.45 ; \mathrm{p}<0.01)$ and prolactin showed a moderate positive correlation with lubrication $(r=0.33 ; p=0.04)$. All these correlations were considered statically significant and can be seen in Table 4.
With regard to sexual hormones and quality of life as assessed by the SF-36, a moderate positive relationship was found between progesterone and limitations due to physical aspects $(r=0.35 ; \mathrm{p}=0.03)$, between SHBG and social aspects $(r=0.35 ; \mathrm{p}=0.03)$ and between cortisol and pain $(r=0.46 ; \mathrm{p}=0.004)$. Amoderatenegativerelationship was found between DHEA and social aspects ( $r=-0.40$; $\mathrm{p}=0.01)$. These correlations were also considered statistically significant and can be seen in Table 5 .

When analyzing the relationship between sexual function and quality of life, it was observed that sexual desire showed a moderate positive correlation with the SF-36 dimensions of vitality $(r=0.46 ; p=0.004)$ and

Table 2 - Hormonal profile of the sample

\begin{tabular}{|c|c|c|c|c|}
\hline Hormone & Minimum & Maximum & Mean & Standard deviation \\
\hline $\mathrm{LH}(\mathrm{mIU} / \mathrm{mL})$ & 11.80 & 76.90 & 40.47 & 16.26 \\
\hline $\mathrm{FSH}(\mathrm{mIU} / \mathrm{mL})$ & 22.7 & 171.1 & 81.88 & 33.11 \\
\hline Estradiol $(\mathrm{pg} / \mathrm{mL})$ & 11.8 & 175.2 & 21.72 & 27.50 \\
\hline Progesterone (ng/mL) & 0.21 & 0.51 & 0.24 & 0.07 \\
\hline T-Total (ng/dL) & 10.0 & 104.8 & 26.34 & 19.84 \\
\hline T-Free $(\mathrm{nmol} / \mathrm{L})$ & 0.003 & 0.056 & 0.01 & 0.01 \\
\hline SHBG $(\mathrm{nmol} / \mathrm{L})$ & 14.3 & 131.0 & 49.73 & 26.84 \\
\hline Cortisol $(\mu \mathrm{g} / \mathrm{dL})$ & 0.7 & 26.4 & 14.11 & 5.00 \\
\hline DHEA $(\mathrm{ng} / \mathrm{mL})$ & 0.4 & 6.6 & 2.09 & 1.29 \\
\hline Prolactin $(\mathrm{ng} / \mathrm{mL})$ & 2.8 & 74.2 & 10.33 & 11.96 \\
\hline Androstenedione $(\mathrm{ng} / \mathrm{mL})$ & 0.30 & 2.54 & 0.73 & 0.44 \\
\hline DHEA-S $(\mu \mathrm{g} / \mathrm{dL})$ & 15.0 & 120.0 & 43.67 & 28.31 \\
\hline
\end{tabular}

DHEA = dehydroepiandrosterone; DHEA-S = dehydroepiandrosterone sulfate; FSH = follicle stimulating hormone; LH = luteinizing hormone; SHBG = sex hormone binding globulin; T-Total $=$ total testosterone; T-Free $=$ free testosterone.

Table 3 - Data on quality of life and sexual function

\begin{tabular}{|c|c|c|c|c|}
\hline & Minimum & Maximum & Mean & Standard deviation \\
\hline \multicolumn{5}{|l|}{ 36-Item Short Form Health Survey } \\
\hline Functional capacity & 10 & 100 & 65.28 & 27.77 \\
\hline Limitations due to physical aspects & 0 & 100 & 48.61 & 43.07 \\
\hline Pain & 0 & 100 & 50.64 & 24.90 \\
\hline General health status & 22 & 92 & 63.17 & 17.13 \\
\hline Vitality & 5 & 90 & 51.53 & 22.35 \\
\hline Social aspects & 13 & 100 & 73.26 & 23.37 \\
\hline Limitations due to emotional aspects & 0 & 100 & 62.04 & 45.88 \\
\hline Mental health & 8 & 100 & 55.44 & 24.77 \\
\hline \multicolumn{5}{|l|}{ Female Sexual Function Index } \\
\hline Desire & 1.2 & 5.4 & 2.32 & 1.02 \\
\hline Arousal & 0.0 & 5.1 & 1.69 & 1.54 \\
\hline Lubrication & 0.0 & 6.0 & 1.89 & 1.91 \\
\hline Orgasm & 0.0 & 5.6 & 1.81 & 1.79 \\
\hline Satisfaction & 0.4 & 6.0 & 2.99 & 1.97 \\
\hline Pain & 0.0 & 6.0 & 2.60 & 2.39 \\
\hline Total score & 1.6 & 31.7 & 13.31 & 9.15 \\
\hline
\end{tabular}


Hormones, quality of life and sexual function - Peixoto et al.

Table 4 - Relationships between hormones and sexual function as assessed by the Female Sexual Function Index (FSFI)

\begin{tabular}{|c|c|c|c|c|c|c|c|c|c|c|c|c|}
\hline & LH & FSH & Estradiol & Progesterone & T-Total & T-Free & SHBG & Cortisol & DHEA & Prolactin & Androstenedione & DHEA-S \\
\hline \multicolumn{13}{|c|}{ 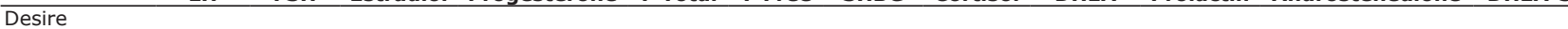 } \\
\hline$r$ & 0.016 & -0.172 & 0.112 & 0.247 & -0.028 & -0.137 & 0.052 & -0.141 & $-0.453 *$ & -0.041 & -0.270 & -0.327 \\
\hline Sig. & 0.924 & 0.316 & 0.514 & 0.147 & 0.873 & 0.427 & 0.762 & 0.411 & 0.006 & 0.812 & 0.112 & 0.051 \\
\hline \multicolumn{13}{|c|}{ Arousal } \\
\hline$r$ & 0.314 & 0.217 & 0.228 & -0.176 & 0.073 & -0.189 & $0.377^{+}$ & 0.165 & -0.098 & 0.308 & -0.124 & -0.136 \\
\hline Sig. & 0.062 & 0.204 & 0.181 & 0.304 & 0.670 & 0.269 & 0.023 & 0.335 & 0.569 & 0.068 & 0.472 & 0.429 \\
\hline \multicolumn{13}{|c|}{ Lubrication } \\
\hline$r$ & 0.262 & 0.228 & 0.211 & -0.259 & 0.039 & -0.168 & 0.315 & -0.112 & -0.165 & $0.331^{+}$ & -0.195 & -0.135 \\
\hline Sig. & 0.123 & 0.182 & 0.218 & 0.127 & 0.821 & 0.329 & 0.062 & 0.514 & 0.335 & 0.049 & 0.255 & 0.431 \\
\hline \multicolumn{13}{|c|}{ Orgasm } \\
\hline$r$ & $0.377^{+}$ & 0.207 & 0.271 & -0.153 & 0.147 & -0.131 & $0.393^{+}$ & 0.185 & -0.112 & 0.251 & -0.078 & -0.148 \\
\hline Sig. & 0.024 & 0.225 & 0.110 & 0.372 & 0.393 & 0.447 & 0.018 & 0.281 & 0.515 & 0.140 & 0.650 & 0.388 \\
\hline \multicolumn{13}{|c|}{ Satisfaction } \\
\hline$r$ & 0.281 & 0.159 & 0.107 & -0.078 & 0.220 & -0.010 & $0.331^{+}$ & 0.228 & -0.034 & 0.110 & -0.039 & -0.197 \\
\hline Sig. & 0.097 & 0.354 & 0.535 & 0.653 & 0.197 & 0.954 & 0.049 & 0.180 & 0.842 & 0.524 & 0.821 & 0.248 \\
\hline \multicolumn{13}{|l|}{ Pain } \\
\hline$r$ & 0.197 & 0.132 & 0.290 & -0.251 & -0.006 & -0.249 & $0.445 *$ & 0.118 & -0.039 & 0.300 & -0.229 & -0.154 \\
\hline Sig. & 0.249 & 0.443 & 0.086 & 0.140 & 0.972 & 0.143 & 0.006 & 0.491 & 0.823 & 0.075 & 0.179 & 0.370 \\
\hline \multicolumn{13}{|c|}{ Total score } \\
\hline$r$ & 0.294 & 0.173 & 0.246 & -0.168 & 0.091 & -0.174 & $0.398^{+}$ & 0.104 & -0.141 & 0.266 & -0.175 & -0.199 \\
\hline Sig. & 0.082 & 0.313 & 0.149 & 0.328 & 0.596 & 0.309 & 0.016 & 0.546 & 0.413 & 0.116 & 0.308 & 0.245 \\
\hline
\end{tabular}

DHEA = dehydroepiandrosterone; DHEA-S = dehydroepiandrosterone sulfate; FSH = follicle stimulating hormone; LH = luteinizing hormone; SHBG = sex hormone binding globulin; T-Total $=$ total testosterone; T-Free $=$ free testosterone.

* Significant correlation at the level of 0.01 (2 extremities)

+ Significant correlation at the level of 0.05 (2 extremities).

Table 5 - Relationships between hormones and quality of life as assessed by the 36-Item Short Form Health Survey (SF-36)

\begin{tabular}{|c|c|c|c|c|c|c|c|c|c|c|c|c|}
\hline & LH & FSH & Estradiol & Progesterone & T-Total & T-Free & SHBG & Cortisol & DHEA & Prolactin & Androstenedione & DHEA-S \\
\hline \multicolumn{13}{|c|}{$\begin{array}{l}\text { Functional } \\
\text { capacity }\end{array}$} \\
\hline$r$ & -0.106 & -0.149 & 0.117 & 0.236 & -0.063 & -0.061 & -0.101 & -0.060 & -0.006 & -0.247 & 0.033 & 0.056 \\
\hline Sig. & 0.539 & 0.387 & 0.497 & 0.166 & 0.716 & 0.724 & 0.559 & 0.730 & 0.975 & 0.147 & 0.846 & 0.747 \\
\hline \multicolumn{13}{|c|}{$\begin{array}{l}\text { Limitations } \\
\text { due to } \\
\text { physical } \\
\text { aspects }\end{array}$} \\
\hline$r$ & 0.067 & 0.044 & 0.187 & $0.352 *$ & -0.149 & -0.144 & 0.090 & 0.154 & -0.143 & -0.192 & -0.062 & 0.120 \\
\hline Sig. & 0.696 & 0.798 & 0.275 & 0.035 & 0.387 & 0.402 & 0.603 & 0.368 & 0.406 & 0.261 & 0.721 & 0.485 \\
\hline \multicolumn{13}{|l|}{ Pain } \\
\hline$r$ & 0.216 & 0.084 & 0.131 & -0.032 & 0.143 & 0.005 & 0.182 & $0.467^{+}$ & -0.009 & -0.128 & 0.147 & 0.089 \\
\hline Sig. & 0.206 & 0.625 & 0.446 & 0.853 & 0.406 & 0.978 & 0.288 & 0.004 & 0.959 & 0.458 & 0.392 & 0.606 \\
\hline \multicolumn{13}{|c|}{$\begin{array}{l}\text { General health } \\
\text { status }\end{array}$} \\
\hline$r$ & -0.012 & -0.103 & 0.204 & 0.158 & 0.151 & 0.123 & -0.078 & -0.285 & -0.022 & -0.034 & 0.176 & 0.014 \\
\hline Sig. & 0.943 & 0.551 & 0.233 & 0.358 & 0.378 & 0.475 & 0.652 & 0.092 & 0.897 & 0.842 & 0.303 & 0.935 \\
\hline \multicolumn{13}{|l|}{ Vitality } \\
\hline$r$ & -0.004 & -0.137 & 0.195 & 0.275 & 0.117 & -0.055 & 0.306 & -0.075 & -0.196 & -0.036 & -0.032 & -0.095 \\
\hline Sig. & 0.983 & 0.424 & 0.253 & 0.104 & 0.496 & 0.751 & 0.070 & 0.665 & 0.251 & 0.834 & 0.853 & 0.582 \\
\hline \multicolumn{13}{|c|}{ Social aspects } \\
\hline$r$ & 0.013 & 0.005 & 0.170 & 0.279 & 0.101 & -0.129 & $0.353 *$ & 0.126 & $-0.405 *$ & 0.156 & -0.004 & -0.136 \\
\hline Sig. & 0.939 & 0.978 & 0.323 & 0.100 & 0.559 & 0.454 & 0.035 & 0.464 & 0.014 & 0.363 & 0.984 & 0.428 \\
\hline \multicolumn{13}{|c|}{$\begin{array}{l}\text { Limitations } \\
\text { due to } \\
\text { emotional } \\
\text { aspects }\end{array}$} \\
\hline$r$ & 0.021 & 0.024 & 0.109 & 0.297 & 0.099 & 0.030 & 0.172 & 0.220 & -0.142 & 0.085 & 0.079 & -0.022 \\
\hline Sig. & 0.905 & 0.891 & 0.527 & 0.079 & 0.565 & 0.861 & 0.316 & 0.197 & 0.408 & 0.620 & 0.646 & 0.900 \\
\hline \multicolumn{13}{|c|}{ Mental health } \\
\hline$r$ & 0.120 & 0.090 & 0.084 & -0.086 & -0.018 & -0.155 & 0.208 & 0.185 & -0.185 & -0.082 & -0.054 & -0.109 \\
\hline Sig. & 0.487 & 0.601 & 0.628 & 0.618 & 0.916 & 0.368 & 0.223 & 0.281 & 0.280 & 0.635 & 0.753 & 0.527 \\
\hline
\end{tabular}

DHEA = dehydroepiandrosterone; DHEA-S = dehydroepiandrosterone sulfate; FSH = follicle stimulating hormone; LH = luteinizing hormone; SHBG = sex hormone binding globulin; $\mathrm{T}$-Total $=$ total testosterone; $\mathrm{T}$-Free $=$ free testosterone.

* Significant correlation at the level of 0.05 (2 extremities).

+ Significant correlation at the level of 0.01 ( 2 extremities). 
social aspects $(r=0.51 ; p=0.001)$. Sexual desire also correlated positively with general health status ( $r=0.35$; $\mathrm{p}=0.03)$ and mental health $(r=0.38 ; \mathrm{p}=0.02)$ of the SF36. Arousal, orgasm and satisfaction with sexual life presented moderate positive relationships with the pain domain of the SF-36 (respectively, $r=0.40, p=0.01$; $r=0.42, p=0.01$; and $r=0.43 . p=0.009)$. The total FSFI score also showed a positive relationship with the pain domain of the SF-36 ( $r=0.37 ; \mathrm{p}=0.02)$. Satisfaction with sexual life presented a weak positive relationship with the vitality domain of the SF-36 $(r=0.33 ; p=0.04)$. These correlations are presented in Table 6.

\section{Discussion}

The relationships found between hormones and sexual function, as well as between sexual hormones and quality of life, draw attention for being the opposite of what would be expected from a pathophysiological point of view. LH is a pituitary hormone involved in the ovulation process. As a result of ovarian failure, an increase in LH production levels is expected, but no relationship between higher levels of $\mathrm{LH}$ and the quality of the orgasm in women is found in the literature, as also observed in this study $(r=0.37 ; p=0.02)$.

SHBG is a glycoprotein that has the function of transporting sexual hormones such as testosterone and estrogens. Higher levels of SHBG indicate a lower amount of bioavailable testosterone. ${ }^{15}$ Taking into consideration the importance of testosterone for sexual function, higher levels of SHBG should have a negative effect on sexual function. However, in the current study, higher levels of SHBG were positively related to three aspects of sexual function assessed by the FSFI: orgasm $(r=0.39 ; p=0.01)$, satisfaction $(r=0.33$; $\mathrm{p}=0.04)$ and pain $(r=0.44 ; \mathrm{p}<0.01)$. These findings indicate that, in this sample, the higher the levels of

Table 6 - Relationships between sexual function and quality of life as assessed by the Female Sexual Function Index (FSFI) and the 36Item Short Form Health Survey (SF-36)

\begin{tabular}{|c|c|c|c|c|c|c|c|c|}
\hline & $\begin{array}{l}\text { Functional } \\
\text { capacity }\end{array}$ & $\begin{array}{l}\text { Limitations due to } \\
\text { physical aspects }\end{array}$ & Pain & $\begin{array}{c}\text { General health } \\
\text { status }\end{array}$ & Vitality & $\begin{array}{c}\text { Social } \\
\text { aspects }\end{array}$ & $\begin{array}{l}\text { Limitations due to } \\
\text { emotional aspects }\end{array}$ & $\begin{array}{l}\text { Mental } \\
\text { health }\end{array}$ \\
\hline \multicolumn{9}{|l|}{ Desire } \\
\hline$r$ & 0.126 & 0.224 & 0.186 & $0.350 *$ & $0.467^{+}$ & $0.511^{+}$ & 0.157 & $0.387 *$ \\
\hline Sig. & 0.462 & 0.188 & 0.277 & 0.037 & 0.004 & 0.001 & 0.369 & 0.020 \\
\hline \multicolumn{9}{|l|}{ Arousal } \\
\hline$r$ & 0.051 & 0.027 & $0.402 *$ & -0.043 & 0.279 & 0.057 & 0.150 & 0.189 \\
\hline Sig. & 0.768 & 0.877 & 0.015 & 0.805 & 0.099 & 0.740 & 0.381 & 0.269 \\
\hline \multicolumn{9}{|c|}{ Lubrication } \\
\hline$r$ & 0.012 & -0.069 & 0.213 & -0.063 & 0.220 & -0.042 & 0.086 & 0.002 \\
\hline Sig. & 0.946 & 0.691 & 0.213 & 0.714 & 0.197 & 0.808 & 0.617 & 0.992 \\
\hline \multicolumn{9}{|c|}{ Orgasm } \\
\hline$r$ & 0.049 & 0.012 & $0.420 *$ & -0.081 & 0.260 & 0.013 & 0.231 & 0.272 \\
\hline Sig. & 0.775 & 0.947 & 0.011 & 0.637 & 0.125 & 0.941 & 0.176 & 0.109 \\
\hline \multicolumn{9}{|c|}{ Satisfaction } \\
\hline$r$ & 0.028 & 0.003 & $0.432^{+}$ & -0.039 & $0.332 *$ & 0.001 & 0.291 & 0.323 \\
\hline Sig. & 0.871 & 0.985 & 0.009 & 0.821 & 0.048 & 0.995 & 0.085 & 0.054 \\
\hline \multicolumn{9}{|l|}{ Pain } \\
\hline$r$ & -0.052 & -0.044 & 0.263 & -0.025 & 0.138 & 0.060 & -0.113 & 0.049 \\
\hline Sig. & 0.761 & 0.797 & 0.122 & 0.883 & 0.421 & 0.728 & 0.512 & 0.777 \\
\hline \multicolumn{9}{|c|}{ Total score } \\
\hline$r$ & 0.027 & 0.007 & $0.375 *$ & -0.012 & 0.303 & 0.076 & 0.138 & 0.210 \\
\hline Sig. & 0.876 & 0.970 & 0.024 & 0.945 & 0.073 & 0.658 & 0.422 & 0.219 \\
\hline
\end{tabular}

* Significant correlation at the level of 0.05 (2 extremities).

+ Significant correlation at the level of 0.01 ( 2 extremities) 
SHBG, the greater the quality of the orgasm, the higher the levels of satisfaction with sexual function and the lesser the genital pain felt during or after intercourse. SHBG also presented a moderate positive correlation with the total FSFI score $(r=0.39 ; \mathrm{p}=0.02)$, indicating that greater levels of SHBG are related to better global sexual functioning.

Prolactin presented a statistically significant, albeit less robust, relationship with vaginal lubrication $(r=0.33$; $p=0.04)$. This is another unexpected result, as a negative correlation between prolactin and testosterone has been demonstrated. ${ }^{15}$ Consequently, vaginal lubrication, one of the variables related to the level of sexual arousal and that is influenced by testosterone, should not present a positive relationship with prolactin.

The only hormone that presented a negative relationship (with statistical significance) with sexual function was DHEA, which was moderately related to the level of sexual desire $(r=0-.45 ; p<0.01)$. Being DHEA an indirect precursor of testosterone, ${ }^{16-18}$ the expected would be to find a positive relationship between this hormone and sexual desire; yet, in this sample, higher levels of DHEA were related to lower sexual desire. Such result contradicts studies that have used DHEA in postmenopausal women and reported improvement in several aspects of sexual function as well as increased DHEA levels in blood. ${ }^{19-21}$

Of the four hormones that presented a statistically significant relationship with the domains of quality of life assessed by the SF-36, three showed results opposite to the expected. Cortisol showed a moderate positive correlation with the pain dimension of the SF$36(r=0.46 ; p=0.004)$. SHBG and DHEA presented correlations with the SF-36 dimension of social aspects ( $r=0.35 ; \mathrm{p}=0.03$ and $r=-0.40 ; \mathrm{p}=0.01$, respectively). Higher levels of cortisol are expected in people with pain. ${ }^{22}$ Considering the action of SHBG on androgens, it would be expected that greater levels of SHBG would indicate greater loss in social aspects - studies have shown that androgen deficiency can cause reduced libido, well-being, mood changes, fatigue and lack of motivation. ${ }^{23,24}$ Some studies have also related greater levels of DHEA with better mood and increased quality of life in some populations. ${ }^{25}$ The only hormone with an expected correlation in our sample was progesterone, which was moderately positively related to physical aspects $(r=0.35 ; p=0.03)$. Although the physical aspects dimension does not specifically assess pain, pain can certainly influence these domain's scores. In addition to the known role of progesterone in reproduction, studies have shown its potential in pain reduction. ${ }^{26}$ It is possible that the action of progesterone on pain justifies the relationship found in this study.
Analysis of the relationship between sexual function and quality of life presented several correlations between the variables of the instruments that assessed these two elements. Sexual desire, assessed by the FSFI, was the aspect of sexual function most strongly related to quality of life. Sexual desire was correlated to the following SF-36 dimensions: social aspects $(r=0.51 ; \mathrm{p}=0.001)$, vitality $(r=0.46 ; \mathrm{p}=0.004)$, mental health $(r=0.38 ; \mathrm{p}=0.02)$ and general health $(r=0.35$; $p=0.03)$. The social aspects dimension assesses the degree to which physical and emotional problems interfere with social activities; vitality assesses how the person feels their level of energy most of the time; mental health assesses aspects related to depression, anxiety and psychological well-being; general health assesses the perception an individual has upon their own health. Satisfaction with sexual life was related to the vitality dimension of the SF-36 $(r=0.33 ; \mathrm{p}=0.04)$. The pain dimension of the SF-36 presented moderate positive correlation with several aspects of sexual function: arousal $(r=0.40 ; \mathrm{p}=0.01)$, orgasm $(r=0.42$; $\mathrm{p}=0.01)$, satisfaction $(r=0.43 ; \mathrm{p}=0.009)$, total score $(r=0.37 ; \mathrm{p}=0.02)$. Considering that sexual function is not a strictly physiological phenomenon ${ }^{27}$ and that good sexual functioning is one of the foundations of quality of life, ${ }^{5}$ these correlations would be common if they occurred in a sample with a more favorable hormonal profile. However, these results raise the hypothesis of the possible existence of psychosocial factors capable of positively influencing sexual function, even in women with an unfavorable hormonal profile. Yet, these data need to be viewed with caution, as several factors that have not been assessed in this study may have positively influenced the correlations.

\section{Limitations}

Sample size and lack of randomization in the participant selection process should be considered as the main limiting factors of this study. Future studies with larger and randomized samples selected from different centers may help improve our understanding of this topic.

\section{Conclusion}

This study aimed to assess the relationship between sexual hormones, sexual function and quality of life in postmenopausal women, and observed several unexpected correlations, when compared to the current literature, regarding the effects of some hormones 
on sexual function and on some aspects of quality of life. These results may indicate an influence of extraphysiological factors on sexual function and quality of life in women with an unfavorable hormonal profile. The results observed in this study can serve as a basis for future studies that aim to improve our understanding of the correlation between sexual function, quality of life and extraphysiological factors in women who reach the end of their fertile life.

\section{Acknowledgements}

This work was supported by Conselho Nacional de Desenvolvimento Científico e Tecnológico (CNPq; grant 449309/2014-2). Clayton Peixoto was a fellow of Coordenação de Aperfeiçoamento de Pessoal de Nível Superior (CAPES) during the conduction of this research.

\section{Disclosure}

No conflicts of interest declared concerning the publication of this article.

\section{References}

1. Pedro AO, Pinto-Neto AM, Costa-Paiva LHS, Osis MJD, Hardy EE. Síndrome do climatério: inquérito populacional domiciliar em Campinas, SP. Rev Saude Publica. 2003;37:735-42.

2. Lui Filho JF, Baccaro LFC, Fernandes T, Conde DM, Costa-Paiva $L$, Pinto NAM. Factors associated with menopausal symptoms in women from a metropolitan region in southeastern Brazil: a population-based household survey. Rev Bras Ginecol Obstet. 2015;37:152-8.

3. Labrie F, Archer D, Bouchard C, Fortier M, Cusan L, Gomez JL, et al. Lack of influence of iyspareunia on the beneficial effect of intravaginal prasterone (dehydroepiandrosterone, DHEA) on sexual dysfunction in postmenopausal women. J Sex Med. 2014; $11: 1766-85$.

4. Meyer $P$. Testosterone therapy in female hypoactive sexual desire disorder. Rev Med Suisse. 2016;12:540-3.

5. De Lorenzi DRS, Saciloto B. Factors related to frequency of sexual activity of postmenopausal women. Rev Assoc Med Bras. 2006;52:256-60.

6. Santos MDS, Sala MG. Climaterio y menopausia. Parte II. La Sexualidad en el climaterio. Sexol Soc. 1999;5:17-9.

7. De Paula FJF, Baracat EC, Haidar MA, Lima JGR, Zanetti A, Simões RD. Disfunção sexual no climatério. Femina. 2002;30:373-6.

8. Tairova OS, De Lorenzi DRS. Influence of exercise in the quality of life of postmenopausal women: a case-control study. Rev Bras Geriatr Gerontol. 2011;14:135-45.

9. Zahar SEV, Aldrighi JM, Pinto NAM, Conde DM, Zahar LO, Russomano F. Quality of life in users and non-users of hormone replacement therapy. Rev Assoc Med Bras. 2005;51:133-8.
10. Dallanezi G, Nahas EAP, Freire BF, Nahas-Neto J, Corrente JE, Mazeto GMFS. Quality of life of women with low bone mass in postmenopause. Rev Bras Ginecol Obstet. 2011;33:133-8.

11. Penteado SRL, Fonseca AM, Bagnoli VR, Assis JS, Pinotti JA. Assessment of orgasmic capacity of postmenopausal women. Rev Assoc Med Bras. 2004;50:444-50.

12. Kulak JJ, Urbanetz AA, Kulak CAM, Borba VZC, Boguszewski CL. Serum androgen concentrations and bone mineral density in postmenopausal ovariectomized and non-ovariectomized women. Arq Bras Endocrinol Metab. 2009;53:1033-9.

13. Pimenta FAP, Simil FF, Tôrres HOG, Amaral CFS, Rezende CFC, Coelho TOR et al. Retiree quality of life assessment with SF-36 Questionnaire. Rev Assoc Med Bras. 2008;54:55-60.

14. Safarinejad MR. Female sexual dysfunction in a population-based study in Iran: prevalence and associated risk factors. Int J Imp Res. 2006;18:382-95.

15. Guyton AC, Hall JE. Tratado de fisiologia médica. $11^{\text {a }}$ ed. New York: Elsevier; 2006.

16. Speroff L, Glass RH, Kase NG. O ovário desde a concepção até a senilidade. In: Speroff L, Glass RH, Kase NG. Endocrinologia ginecológica clínica e infertilidade. $5^{a}$ ed. São Paulo: Manole; 1995.

17. Wajchenberg BL. Tratado de endocrinologia clínica. São Paulo: Roca; 1992.

18. Wolkowitz OM, Rothschild AJ. Psychoneuroendocrinology: the scientific basis of clinical practice. Washington: American Psychiatric Publishing; 2003.

19. Genazzani AR, Stomati M, Valentino V, Pluchino N, Pot E, Casarosa $E$, et al. Effect of 1-year, low-dose DHEA therapy on climacteric symptoms and female sexuality. Climacteric. 2011;14:661-8.

20. Labrie F, Archer D, Bouchard C, Fortier M, Cusan L, Gomez JL, et al. Lack of influence of dyspareunia on the beneficial effect of intravaginal prasterone (dehydroepiandrosterone, DHEA) on sexual dysfunction in postmenopausal women. J Sex Med. 2014;11:1766-85.

21. Bloch M, Meiboom H, Zaig I, Schreiber S, Abramov L. The use of dehydroepiandrosterone in the treatment of hypoactive sexual desire disorder: a report of gender differences. Eur Neuropsychopharmacol. 2013;23:910-8.

22. Anand KJS, Phil D, Hickey PR. Pain and its effects in the human neonate and fetus. N Engl J Med. 1987;317:1321-9.

23. Leão LMCSM, Duarte MPC, Farias MLF. Insuficiência androgênica na mulher e potenciais riscos da reposição terapêutica. Arq Bras Endocrinol Metab. 2005;49:205-16.

24. Helena PF, Alessandro $S$, Tsutomu $A$, José MA. Deficiência androgênica na mulher. Rev Assoc Med Bras. 2010;56:579-82.

25. Peixoto C, Cheda JND, Nardi AE, Veras AB, Cardoso A. The effects of dehydroepiandrosterone (DHEA) in the treatment of depression and depressive symptoms in other psychiatric and medical illnesses: a systematic review. Curr Drug Targets. 2014;15:90114.

26. Viana ESR, Bruno SS, Sousa MBC. Modulation by progesterone of pain sensitivity to mechanical and ischemic stimuli in young and healthy women. Rev Bras Ginecol Obstet. 2008;30:306-11.

27. Valença CN, Nascimento FJM, Germano RM. Women in the climacteric: reflections on sexual desire, beauty and femininity. Saude Soc. 2010;19:273-85.

\section{Correspondence:}

Clayton Peixoto

Laboratório de Pânico e Respiração, Instituto de Psiquiatria (IPUB)

Universidade Federal do Rio de Janeiro (UFRJ)

Av. Venceslau Braz, 71, Botafogo

22290-140 - Rio de Janeiro, RJ - Brazil

Fax: +55 (21) 25433103

E-mail: claytonpeixoto@yahoo.com.br 